\title{
THE GROUND BEETLE (COLEOPTERA: CARABIDAE) COMMUNITY IN AN INTENSIVELY MANAGED AGRICULTURAL LANDSCAPE
}

\author{
LEMIC, D. - Č́AČIJA, M. - VIRIĆ GAŠPARIĆ, H. - DRMIĆ, Z. - BAŽOK, R. - \\ PAJAČ ŽIVKOVIĆ, I.
}

\author{
University of Zagreb, Faculty of Agriculture, Department of Agricultural Zoology \\ Svetošimunska 25, 10000 Zagreb, Croatia \\ *Corresponding author \\ e-mail:dlemic@agr.hr; phone: +385-1-2393-804
}

(Received 28 ${ }^{\text {th }}$ Apr 2017; accepted 20 ${ }^{\text {th }}$ Jul 2017)

\begin{abstract}
The effects of intensive agricultural management practices and environmental changes on biodiversity can be monitored by using the carabid beetles as biological indicators of agroecosystems quality. This study aimed to investigate the ground beetle species composition, abundance, dominance, diversity, zoogeographical types and distribution groups in an intensively managed agricultural field. Epigeic carabid fauna was collected weekly using pitfall traps on an arable crop field in Podravina, Croatia. Altogether, 1429 individuals belonging to 26 species and 15 genera were collected. The most abundant and eudominant were Poecilus cupreus (Linnaeus, 1758), followed by Brachinus psophia Audinet-Serville, 1821 and Pterostichus melas melas (Creutzer, 1799). Two species were dominant, two subdominant, four recedent and 15 subrecedent. The diversity of fauna was moderately high: Simpson diversity index 0.7875, Shannon-Wiener index 1.9654 and Pielou's evenness 0.6032. Zoogeographical analysis showed equal dominance of Euroasian and Palearctic species. Most (73\%) of species belonged to $\mathrm{E}$ and $27 \%$ to A relict class. The majority of species were spring breeders (14 species), 8 species were autumn breeders and one species breeds in both seasons. In intensively managed agricultural landscape, ground beetle diversity was moderately high, because most of the species were eurytopic, i.e. capable of inhabiting strongly anthropogenically influenced landscapes.
\end{abstract}

Keywords: Carabidae species composition, ecological factors, zoogeographical types, intensive crop production, agro-technical measures

\section{Introduction}

Ground beetles are species rich and abundant in agricultural land all over the world (Lövei and Sunderland, 1996). As one of the most abundant and diverse groups overwintering within cultivated fields (Holland and Reynolds, 2003), they are often used in cultivation experiments. Carabids have also been successfully used for different kinds of indicator studies, serving as biological indicators of agroecosystems quality (Cole et al., 2002; O'Rourke et al., 2008). Most of these studies focus on beetles' response to agricultural management practices or changing environmental conditions (Rainio and Niemelä, 2003). According to Baranova et al. (2013), in terms of environmental quality, arable land represents an anthropogenically influenced, unstable and devastated biotope with low contribution to farmland diversity. Due to ground beetles' sensitive reaction to anthropogenic changes in habitat quality (Avg1n and Luff, 2010), they have a bioindicative value for cultivation impacts, as well as for environmental change (Thiele, 1977; Maelfait, 1990).

Environmental change, through many abiotic and biotic factors, can cause different kinds of effects on the indicator species, including changes in species 
number and distribution (Blake et al., 1996; Rainio and Niemelä, 2003). Abiotic factors most often include temperature and soil moisture (Lövei and Sunderland, 1996; Holland, 2002). Other authors reported on many additional factors: landscape heterogeneity (Chapman, 2014), field size (Kromp, 1999), the presence of non-cropped habitat (Pollard, 1968; Sotherton, 1985) and land use diversity (Östman et al., 2001). Ground beetle abundance can be influenced by the cropdependent timing of cultivation measures (Hence et al., 1990). According to Stassart and Grégoire-Wibo (1983), the depth of tillage is one of the major factors affecting the carabid fauna. Fertilization regimes (e.g. manure, mineral fertilizers) could also have a positive effect on ground beetle population (Pietraszko and De Clercq, 1982; Hence and Grégoire-Wibo, 1987) or a negative one (Kromp, 1990). Vician et al. (2015) considered the content of organic matter and $\mathrm{pH}$ as the most significant factors influencing ground beetle diversity in agroecosystems, while others stated soil particle size distribution can be a decisive factor in habitat selection (Thiele, 1977; Meissner, 1984).

Crop type can affect ground beetles through modification of microclimatic factors (i.e. temperature and humidity) and through disturbance factors (i.e. harvest and tillage schedules) (Thiele, 1977; Witmer et al., 2003; O'Rourke et al., 2008). The ground beetles population in the agricultural landscape can be also influenced by chemical pest control (Basedow, 1987; Asteraki et al., 1992; Jeschke et al., 2011; Szczepaniec et al., 2011; Varvara et al., 2012; Douglas et al., 2014).

Several studies in Croatia reported about epigeic ground beetles' assemblage, distribution and abundance in different vegetation types, including forests (Šerić Jelaska, 2005; Brigić et al., 2014a), wetlands (Brigić et al., 2014b), meadows (Durbešić, 1987; Durbešić et al., 2006) and parks (Durbešić, 1982; Marković, 2009). However, not many detailed studies about ground beetles on agricultural fields with intensive land cultivation have been done. Studies were performed on leguminous fields (Kovačević and Balarin, 1960; Balarin, 1974) and in wheat (Sekulić et al., 1973; Sekulić, 1977). The most comprehensive ground beetle faunal study on several different crop types was done in Podravina region more than 30 years ago (Štrbac, 1983), in which 31 species were identified. Since then, only few researchers investigated ground beetle assemblage in agricultural landscape, and these included research on sugar beet (Kos et al., 2013), maize (Kos et al., 2006; Bažok et al., 2007; Kos et al., 2011) and barley (Kos et al., 2010). The latest study on endogeic ground beetle communities in arable field in Podravina area revealed eight species (Drmić et al., 2016). Juran et al. (2013) investigated activity of the adult ground beetles in three differently managed fields in central Croatia and found that the endogaeic activity was highest in „organic" system, followed by the „,conventional“ and ,integrated“ system. Büchs et al. (2013) found 72 species on differently managed fields in a neighboring country. The authors, however, did not mention the species composition.

Different indices measure different aspects of the partition of abundance between species. Species evenness usually has been defined as the ratio of observed diversity to maximum diversity, the latter being said to occur when the species in a collection are equally abundant (Margalef, 1958; Patten, 1962; Pielou, 1966). Simpson's index, for example, is sensitive to the abundance only of the more plentiful species in a sample, and can therefore be regarded as a measure of "dominance concentration" (Whittaker, 1965). Used Shannon index is an 
information statistic index, which means it assumes all species are represented in a sample and that they are randomly sampled. This index estimates the affinity of different populations belonging to a community and, through the species composition, the similarity of the habitats (Popescu and Zamfirescu, 2004).

In modern intensively managed production in Croatia, there is still little knowledge on beneficial fauna importance (Bažok et al., 2015; Virić Gašparić et al., 2017). In order to preserve biodiversity in intensively managed arable land as much as possible, it is important to monitor the bioindicator species such as ground beetles, since they can indicate the anthropogenically influenced field quality. Detailed knowledge on their community in a specific agricultural landscape can give us a preview on agroecosystem stability. Therefore, this study aimed to investigate the ground beetle species composition, abundance, dominance and diversity, as well as zoogeographical types and distribution groups in an intensively managed agricultural field, with its specific agro-ecological factors and agro-technical measures.

\section{Materials and methods}

\section{Location}

Ground beetles were collected during the arable crop growing season in 2015 in Lukač (Virovitica-Podravina County, Croatia), on winter crop field with an intensive arable management and specific climatic and edaphic characteristics (field size 34.76 ha, coordinates: $45^{\circ} 50^{\prime} 24^{\prime \prime} \mathrm{N}, 17^{\circ} 24^{\prime} 0^{\prime \prime}$ E). According to Köppen classification, this part of continental Croatia belongs to Cfwbx climatic type characterized with continental climate of cold winters and hot summers (Penzar and Penzar, 2000). The soils in the research area are gleyic luvisols (IUSS Working Group WRB 2015). These are hydromorphic soils, characterized by periodic or continuous wetting of part or whole of the profile, with stagnating precipitation or with additional surface or underground water that is not saline or alkaline. These soils contain a great amount of fine sand and coarse silt (sandy loams texture) (Bogunović et al., 1996) and often require conventional tillage.

The field was chosen to represent common cultivation practices as well as the agro-technical measures in this area. Considering the soil type and soil characteristics, the tillage was adapted to the given conditions and performed as follows: a) in autumn: ploughing on a depth of 20-25 cm was followed by the furrow closure for moisture conservation in spring; b) in spring: chisel ploughing and tillage with the rotary harrow; c) in summer: after harvest disk harrowing and again chisel ploughing. A description of the regional physical and chemical soil properties of investigated area as well as agrotechnical measures applied on the experimental field are given in Table 1. Performed pedological procedure consisted out of taking the soil sample from the depth of a plow layer $(30 \mathrm{~cm})$. Five subsamples waging 300-400 g were taken and than pooled and homogenized for analysis. Analysis was performed by the pedology laboratory of the Department of Soil Science, Faculty of Agriculture, University of Zagreb and included sediment grain size and chemical properties analyses. Soil texture was determined by sieving following standard methods (ISO 11277 2004) (Kozina et al., 2015). 
Table 1. Physical and chemical soil properties of arable field where research was conducted

\begin{tabular}{|c|c|c|c|c|c|c|c|}
\hline Location & $\begin{array}{l}\text { Soil } \\
\text { type }\end{array}$ & $\begin{array}{l}\text { Soil } \\
\text { pH }\end{array}$ & $\begin{array}{c}\text { Humus } \\
(\%)\end{array}$ & $\begin{array}{l}\text { Soil properties } \\
(\mathrm{mm})\end{array}$ & Fertilization & $\begin{array}{c}\text { Bare } \\
\text { soil } \\
\text { (mth)* }\end{array}$ & $\begin{array}{l}\text { Insecticide } \\
\text { treatment }\end{array}$ \\
\hline $\begin{array}{c}\text { Lukač } \\
\text { (Virovitica } \\
\text {-Podravina } \\
\text { County) }\end{array}$ & $\begin{array}{l}\text { gleyic } \\
\text { luvisol }\end{array}$ & $\begin{array}{l}\mathrm{KCl} \\
5.58 \\
\\
\mathrm{H} 2 \mathrm{O} \\
6.65\end{array}$ & 3.2 & $\begin{array}{c}\text { Coarse sand } \\
2.35 \\
\text { Fine sand } 11.83 \\
\text { Coarse silt } \\
38.42 \\
\text { Fine silt } \\
31.65 \\
\text { Clay } \\
15.75\end{array}$ & $\begin{array}{l}74 \mathrm{~kg} \mathrm{~N} \\
60 \mathrm{~kg} \mathrm{P} \\
90 \mathrm{~kg} \mathrm{~K}\end{array}$ & 2 & Thiacloprid \\
\hline
\end{tabular}

*number of months while field was not covered after harvesting till soil preparing for crops grown in folowing vegetation season

\section{Climatic factors}

Climate data (i.e., mean weekly air temperature, mean weekly soil temperature and the total amount of rainfall per week) were obtained from the Croatian Meteorological and Hydrological Service and presented for ground beetle collecting period from May to September $2015\left(19^{\text {th }}\right.$ to $38^{\text {th }}$ week of the year $)$.

\section{Ground beetle trapping}

Epigeic covered pitfall traps were used to collect adult ground beetles. Polythene pots $(\varnothing=12 \mathrm{~cm}, \mathrm{~h}=18 \mathrm{~cm})$ were incorporated $18 \mathrm{~cm}$ into the soil and covered with PVC roofs $(\varnothing=16 \mathrm{~cm})$ approximately $4 \mathrm{~cm}$ above ground level. Each trap was half filled with salted water $(20 \%$ solution) for captures conservation. Four pitfall traps were placed into the center of the field at $50 \mathrm{~m}$ apart and $100 \mathrm{~m}$ away from the field edges. Trapping was performed from the $19^{\text {th }}$ to the $38^{\text {th }}$ week of the year, from May to September 2015. Traps were inspected once a week and all ground beetles were collected and counted. The identification of the collected ground beetles to species level was based on the work of Auber (1965), Bechyne (1974), Harde and Severa (1984) and Freude et al. (2006).

\section{Ground beetle composition analysis}

The ground beetle trapping results using pitfall traps for the selected interval (from $19^{\text {th }}$ to $38^{\text {th }}$ week of the year) are presented as a mean number of individuals caught per field per week. Results of the ground beetle population dynamics are presented as the total number of ground beetles caught per week as a function of the average weekly air temperatures $\left({ }^{\circ} \mathrm{C}\right)$, total weekly precipitation $(\mathrm{mm})$ and average weekly temperature of soil $\left({ }^{\circ} \mathrm{C}\right)$ at a depth of $10 \mathrm{~cm}$.

The dominance values of carabids presented in percentage shares of a particular species in the community were calculated according to Tischler (1949) as follows: eudominant (10-100\%), dominant (5-10\%), subdominant (2-5\%), recedent (1-2\%) and subrecedent $(<1 \%)$. To calculate the diversity of the carabid assemblages, Simpson $(\lambda)$ and Shannon-Wiener indices $\left(\mathrm{H}^{\prime}\right)$ were used. Shannon-Wiener indices is an entropy, giving the uncertainty in the outcome of a sampling process key (Jost, 2006). Both 
Shannon and Simpson diversities increase as richness increases, for a given pattern of evenness, and increase as evenness increases, for a given richness, but they do not always rank communities in the same order (Colwell, 2009). Evenness was estimated using Pielou's evenness. Analyses were carried out using the MATLAB program (The MathWorks Inc., 2015). Zoogeographical analysis adding new species records and contributing an understanding of the composition (Majka et al., 2007), was made according to Vigna Taglianti et al. (1999) and the database Fauna Europaea (Vigna Taglianti, 2013). The distribution/occurrence groups (relict classes E, A and R) were defined according to Hůrka et al. (1996).

\section{Results and discussion}

This study aimed at observation and description of a ground beetle fauna during one vegetation season in intensive arable crop production. During the sampling period, a total of 1429 individuals were collected using epigeic traps at Podravina region. Ground beetles collected belong to 26 species and 15 genera (Table 2) which in comparison with previous studies in arable agroecosystems can be classified as moderately high (Kos et al., 2006; Bažok et al., 2007; Kos et al., 2010, 2011; Drmić et al., 2016; Virić Gašparć et al., 2017). Despite the large number of species which may occur in agroecosystems, a relatively small number have been identified as being characteristic of arable areas and these are often the most abundant (Thiele, 1977; Holland and Luff, 2000).

The composition of recorded species in arable crops corresponds with results of similar investigations in Croatia (Kos et al., 2006; Bažok et al., 2007; Igrc Barčić et al., 2008; Kos et al., 2010; 2011; Drmić et al., 2016) and abroad (Bukejs and Balalaikins, 2008; Woodcock et al., 2010; Baranová et al., 2013). The most abundant species in the total catch was Poecilus (Poecilus) cupreus cupreus (Linneaus, 1758) (37.65\%) followed by Brachinus (Brachinus) psophia Audinet-Serville, 1821 (21.06\%) and Pterostichus (Feronidius) melas melas (Creutzer, 1799) (10.29\%) (Table 2). The most abundant species accounted almost $70 \%$ of the total catch and belonged to the group of eudominant species. Anchomenus (Anchomenus) dorsalis (Pontoppidan, 1763) and Harpalus (Pseudoophonus) rufipes (DeGeer, 1774) were classified as dominant, Amara (Amara) similata (Gyllenhal, 1810) and Pterostichus (Morphosoma) melanarius melanarius (Illiger, 1798) as subdominant while others were recedent (4 species) or subrecedent (15 species). The species, which dominated the carabid assemblage in arable habitat (with the total collections), were P. cupreus (538), B. psophia (301), P. melas (147), H. rufipes (128) and A. dorsalis (97) (Table 2).

Species $P$. cupreus is considered as one of the most common species inhabitating winter crops (Alford, 2008), so these results strongly support this research. In Croatia, Štrbac (1983) also specified it among the three most dominant on arable land.

Drmić et al. (2016) investigated endogaeic ground beetle fauna in the same area in Croatia and detected B. psophia and A. dorsalis as the most abundant ones, therefore we may assume that these species are a typical arable ground beetle representatives in investigated region.

Species P. melas is also common in Croatia and was detected as dominant in agricultural land near the Nature park Lonjsko polje (Brigić et al., 2003). 
Table 2. The composition, abundance, zoogeographical and geographical analysis of ground beetles collected in Lukač, 2015

\begin{tabular}{|c|c|c|c|c|c|}
\hline Species name & $\mathbf{N}^{\dagger}$ & $\mathbf{D V}^{*}$ & $\begin{array}{c}\text { Zoogeographical } \\
\text { categories and } \\
\text { faunal types } \\
\S\end{array}$ & $\begin{array}{c}\text { Geographical } \\
\text { distribution } \\
\text { groups }\end{array}$ & $\begin{array}{c}\text { Reproduction } \\
\text { period }^{\Phi}\end{array}$ \\
\hline Calosoma (Campalita) auropunctatum auropunctatum Herbst, 1784 & 1 & 0.07 & E-CAS & A & no data found \\
\hline Brachinus (Brachinus) crepitans Linné, 1758 & 27 & 1.89 & B-CAS & $\mathrm{E}$ & $\mathrm{Sp}$ \\
\hline Brachinus (Brachinus) psophia Audinet-Serville 1821 & 301 & 21.06 & E-CAS & $\mathrm{E}$ & no data found \\
\hline Brachinus (Brachynidius) explodens Duftschmid 1812 & 3 & 0.21 & E-CA-M & $\mathrm{E}$ & $\mathrm{Sp}$ \\
\hline Clivina fossor fossor Linné, 1758 & 13 & 0.91 & E-AS & $\mathrm{E}$ & $\mathrm{Sp}$ \\
\hline Asaphidion curtum curtum Heyden 1870 & 3 & 0.21 & OLA & $\mathrm{E}$ & $\mathrm{Sp}$ \\
\hline Trechus (Trechus) quadristriatus Schrank, 1781 & 4 & 0.28 & E-CA-M & $\mathrm{E}$ & $\mathrm{A}$ \\
\hline Anisodactylus (Pseudanisodactylus) signatus Panzer 1796 & 1 & 0.07 & E-AS & $\mathrm{E}$ & $\mathrm{Sp}$ \\
\hline Harpalus (Harpalus) affinis Schrank, 1781 & 1 & 0.07 & E-AS & $\mathrm{E}$ & $\mathrm{Sp}$ \\
\hline Harpalus (Harpalus) dimidiatus P. Rossi, 1790 & 1 & 0.07 & E-PAS & A & $\mathrm{A}$ \\
\hline Harpalus (Harpalus) distinguendus distinguendus Duftschmid, 1812 & 2 & 0.14 & PAL & $\mathrm{E}$ & $\mathrm{Sp}$ \\
\hline Harpalus (Pseudoophonus) rufipes DeGeer, 1774 & 128 & 8.96 & PAL & $\mathrm{E}$ & A \\
\hline Stenolophus (Stenolophus) teutonus Schrank, 1781 & 16 & 1.12 & E-MED & $\mathrm{E}$ & $\mathrm{Sp}$ \\
\hline Agonum (Amara) viridicupreum viridicupreum Goeze, 1777 & 1 & 0.07 & E-PA-M & $\mathrm{E}$ & $\mathrm{Sp}$ \\
\hline Anchomenus (Anchomenus) dorsalis Pontoppidan, 1763 & 97 & 6.79 & PAL & $\mathrm{E}$ & $\mathrm{Sp}$ \\
\hline Abax (Abacopercus) carinatus carinatus Dejean, 1828 & 4 & 0.28 & E-PAS & $\mathrm{A}$ & no data found \\
\hline Abax (Abax) parallelepipedus parallelepipedus Piller \& Mitterpacher, 1783 & 1 & 0.07 & EUR & A & $\mathrm{A}$ \\
\hline Poecilus (Poecilus) cupreus cupreus Linné, 1758 & 538 & 37.65 & E-AS & $\mathrm{E}$ & $\mathrm{Sp}$ \\
\hline Pterostichus (Feronidius) melas melas Creutzer, 1799 & 147 & 10.29 & E-PAS & $\mathrm{A}$ & $\mathrm{A}$ \\
\hline Pterostichus (Morphosoma) melanarius melanarius Illiger, 1798 & 54 & 3.78 & E-SI & $\mathrm{A}$ & $\mathrm{A}$ \\
\hline Pterostichus (Platysma) niger niger Schaller, 1783 & 1 & 0.07 & E-AS & $\mathrm{A}$ & $\mathrm{A}$ \\
\hline Calathus (Calathus) fuscipes fuscipes Goeze, 1777 & 19 & 1.33 & PAL & $\mathrm{E}$ & $\mathrm{A} / \mathrm{Sp}$ \\
\hline Calathus (Neocalathus) ambiguus ambiguus Paykull, 1790 & 1 & 0.07 & E-AS & $\mathrm{E}$ & A \\
\hline Amara (Amara) aenea Degeer, 1774 & 3 & 0.21 & OLA & $\mathrm{E}$ & $\mathrm{Sp}$ \\
\hline Amara (Amara) ovata Fabricius, 1792 & 28 & 1.96 & PAL & $\mathrm{E}$ & $\mathrm{Sp}$ \\
\hline Amara (Amara) similata Gyllenhal, 1810 & 34 & 2.38 & E-AS & $E$ & $\mathrm{Sp}$ \\
\hline
\end{tabular}

$\dagger$-number of individuals; $\$$ DV-dominance index; $\S$ I. Northern Holarctic and Euro-Siberian faunal type: OLA - Holarctic; PAL - Palearctic; E-SI - Eurosiberian; II. European faunal type: EUR - European; E-PAS - European-Neareastern; III. Euroasiatic faunal type: E-AS - Euroasiatic steppe complex; E-CAS - European and Central Asian; B-CAS - Balkan and Central Asian; IV. Mediterranean (s. lato) faunal type: E-CA-M - European-Centralasian-Mediterranean; E-PA-M - EuropeanNeareastern-Mediterranean; E-MED - Eastmediterranean (Vigna Taglianti et al. 1999, the database Fauna Europaea (Vigna Taglianti, 2013)); | Relict classes: Eeurytopic species, A-adoptable species; \ A-autumn, Sp-spring. 
Kromp (1999) listed species $H$. rufipes, followed by $P$. cupreus and $P$. melanarius as the most abundant from agricultural fields of Eastern European countries, which is generally in accordance with our results. Similar investigations from Croatia (Bažok et al., 2007; Igrc Barčić et al., 2008; Kos et al., 2011) also stated species $H$. rufipes and $P$. melanarius in the group of the most abundant species in corn fields. Although they were not the most abundant species in our results, they were among species which generally dominated with the total scores.

This typically structured ground beetle community of arable land consists of a small number of dominant species represented with a large number of individuals and a large number of less commonly occurring species (subdominant, recedent and subrecedent) represented with a low number of specimens (Baranová et al., 2013).

The diversity of fauna was moderately high: Simpson $\left(1-\lambda^{\prime}\right)$ diversity index was 0.7875, Shannon-Wiener index $\left(\mathrm{H}^{\prime}\right)$ was 1.9654 and Pielou's evenness was 0.6032 . Analysis of faunal types (zoogeographical analyses) showed the dominance of Euroasian $(23.08 \%)$ and Palearctic $(23.08 \%)$ species which corresponds with climatic and geographic characteristics of the investigated area (Table 2).

With reference to relict classes, $73 \%$ of determined ground beetles belonged to $\mathrm{E}$ relict class which consists of eurytopic species without special demands on habitat type and quality, and inhabiting strongly anthropogenically influenced landscapes (Hůrka et al., 1996). Species which belonged to A relict class were represented with $27 \%$ and this group included more adoptable species, which are found in more or less natural habitats (forests, meadows, pastures, standing and flowing water) (Hůrka et al., 1996). Neither one species was classified to relict class $\mathrm{R}$, which was expected, because $\mathrm{R}$ class includes species with narrow ecological amplitude, which are rare and endangered, occurring naturally in undisturbed ecosystems which was not the case in our study (Hůrka et al., 1996). These results correspond to the results of Porhajašová et al. (2004) and Baranová et al. (2013) who reported that increasing human disturbances changes the composition to favor eurytopic species while reducing the number of specialized species with narrow ecological valences.

Abundance and diversity as well as the ratio of spring to autumn breeders varied between winter sown crops (cereals and oilseed rape) and spring sown root crops (potatoes, sugar beet, maize, carrots) (Kabacik-Wasylik, 1975 cit. Holland and Luff, 2000). Winter crops usually have higher abundance, diversity and more spring breeders with summer larvae (e.g. P. cupreus, A. dorsalis) which was confirmed with our results as well. These preferences are not, however, always apparent and even total numbers may vary (Holland and Luff, 2000). The majority of collected species were spring breeders (14 species), 8 species were autumn breeders and one species (Calathus fuscipes fuscipes (Goeze, 1777)) breeds in both seasons (Table 2). The domination of spring breeders could be a consequence of the cultivation measures. The depth of tillage is one of the major factors affecting field carabid communities, with superficial ploughing enabling a higher number of species and favoring spring breeders (Kromp, 1999 cit. Stassart and Grégoire-Wibo, 1983).

Species composition and the number of ground beetles in different agrocenosis differ and depend on edaphic factors (Bukejs and Balalaikins, 2008). Ground beetle species contribute significantly to the insect diversity in farmland because many species are adapted to agriculture and generally occur at high densities (Booij, 1994). According to Thiele (1977) and Kromp (1999) cultivated land is comprised of widely distributed, eurytopic ground beetle species, many of which have high tolerance to disturbances and 
chemical pollution. This means that cultivated land contains a typical ground beetle fauna, despite the regular implementation of cultivation measures (Kromp, 1999). For example, Thiele (1977) listed 26 species found at investigated arable habitats stretching from England over Central Europe.

In our survey the first population maximum was observed from week 19th to 21st which was also the beginning of sample collection period. The second population maximum was recorded from week 32nd to 36th (Figure 1). Presented results of ground beetle population dynamics show that population increase follows air and soil temperature decrease (Figure 1). In the whole investigation period the number of ground beetle decrease is followed by precipitation increase. Recording to Croatian Meteorological and Hydrological Service the Virovitica-Podravina County is described as mid worm area with intensive periods of rainfall especially in summer period.

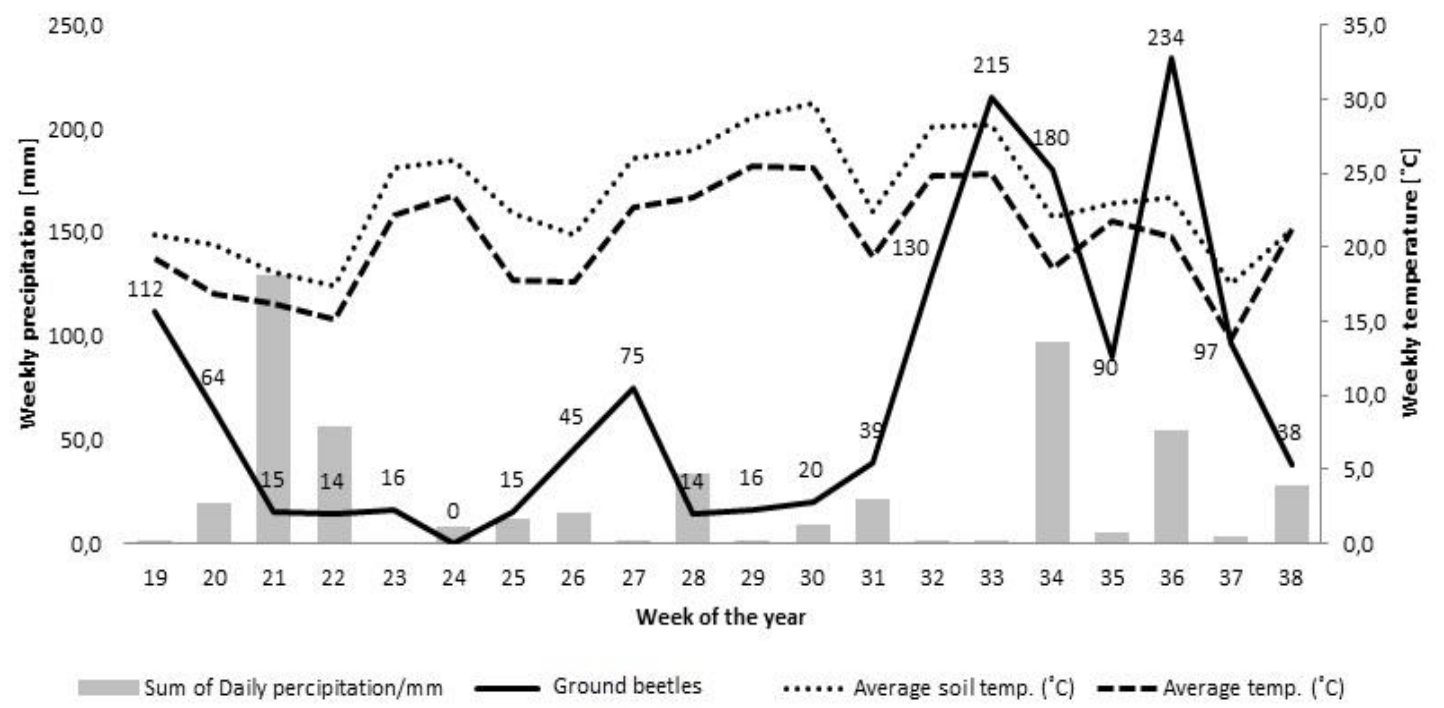

Figure 1. Ground beetles weekly dynamics with prevailing climatic conditions

According to edaphic factors prevailing at investigation area ground beetles inhabited slightly acidic soil with a great amount of fine silt and a small proportion of clay (Table 1). The intensity of ploughing was the main agro-technical specificity at studied locality. The field in Podravina has been ploughed often and on great depth during whole vegetation season. Ploughing is known to significantly influence physicochemical and biological soil properties and affects the abundance of invertebrates (Vician et al., 2015). Generally, reduced soil disturbance, increased surface residues and greater weed diversity had positive impact on invertebrates (Kromp, 1999). According to previous studies, higher ground beetle trapping rates were recorded on fields with reduced tillage or no tillage at all compared with conventionally tilled ones (House and All, 1981; Blumberg and Crossley, 1983; House and Stinner, 1983; Ferguson and McPherson, 1985; House and Parmalee, 1985; Stinner et al., 1988; Tonhasca, 1993). Conventional tillage, such as conducted on the field in Podravina, could have an impact on established ground beetles abundance.

The soil factors are greatly influenced by weather conditions and ploughing but also could be affected by crops growing at the area. Previous studies have shown that microclimatic factors, such as temperature and humidity, and disturbance factors such 
as harvest and tillage schedules crops affect ground beetles communities (Thiele, 1977; Holland, 2002). Although no ground beetle species appears to be strictly bound to a certain crop, early agro-ecological studies in Europe reported a general difference between ground beetle abundance distributions in winter versus spring crops (Heydemann, 1955). O'Rourke et al. (2008) stated that thick stand winter crops provide important refuges for ground beetles in comparison with spring crops. The overwintering crop sown at the field in our survey may confirm the importance of crop habitat for supporting ground beetle populations by providing less extreme microhabitat in spring and creates positive conditions for ground beetle survival and the dominance of spring breeders.

Beside crop specifics, bare soil period can also be a significant factor that affects ground beetle communities. In winter crops, the less extreme microclimate already established in early spring creates favorable conditions for ground beetles (Kromp, 1999). Locality in our study had a very short period of bare soil (2 months period without plant cover; Table 1). No negative effect was observed in ground beetle populations regarding the extreme soil surface microclimate. The effect of intensively managed crop on ground beetles abundance which could be detected in this research support the results of numerous other studies (Tonhasca, 1993; Zhang et al., 1998; Honek and Jarosik, 2000; Ward and Ward, 2001; Witmer et al., 2003; O'Rourke et al., 2008).

As well, the fertilization in Podravina is generally intensive while insecticide treatments were common and in compliance with IPM. While previous studies had concluded that insecticides have negative influence on the ground beetle populations (Asteraki et al., 1992, 1995), more detailed investigation are needed for the full conclusion. Kromp (1999) shown that high amount of nitrogen used in fertilization process decrease ground beetle abundance. The levels of nitrogen applied in Podravina are under permitted levels (EU Directive 2009/128/EC, EUR-Lex, 2009) causing minimal negative influence on ground beetles. Only mineral fertilization has been used in Podravina so possible positive effect of organic manure recorded by Pietraszko and De Clercq (1982) and Hence and Grégoire-Wibo (1987) on ground beetle communities cannot be discussed.

\section{Conclusions}

The bioindicator species such as ground beetles have not received much attention by researchers in Croatia, although they can indicate the anthropogenically influenced field quality. In this study we gained detailed knowledge on their community in a specific agricultural landscape in northwest Croatia, Podravina region. In this investigation, a total of 1429 ground beetles were collected using epigeic traps, belonging to 26 species and 15 genera. Ground beetle diversity was moderately high, because most of the species were eurytopic, i.e. capable of inhabiting strongly anthropogenically influenced landscapes. In modern agriculture in European Union, conservation programs aimed to keep beneficial species and biodiversity are promoted as tool for ensuring sustainability. In order to measure the success of such programs, one has to have detailed knowledge on the initial situation. The results of this study significantly contributed to better understanding of initial situation about ground beetle communities in intensive agricultural landscape in northwest Croatia and will be a good entry point for future conservation programs. 
Acknowledgements. We give great gratitude to family farm Katančić for conceding the field where the research was conducted. Special appreciation goes to taxonomy expert Mr Teun van Gijzen for help in identifying the ground beetle species. The study was funded by the European Union from the European Social Fund within the project "Improving human capital by professional development through the research program in Plant Medicine," HR.3.2.01-0071.

\section{REFERENCES}

[1] Alford, D.V., Büchs, W., Prescher, S., Kromp, B., Ulber, B. (2008): Taxonomy and identification of predators. - In: Alford, D.V. (ed.) Biocontrol of Oilseed Rape Pests, Blackwell, Oxford, UK.

[2] Asteraki, E.J., Hanks, C.B., Clements, R.O. (1992): The impact of two insecticides on predatory ground beetles (Carabidae) in newly-sown grass. - Annals of Applied Biology 120(1): 25-39.

[3] Asteraki, E.J., Hanks, C.B., Clements, R.O. (1995): The influence of different types of grassland field margin on carabid beetle (Coleoptera: Carabidae) communities. Agriculture Ecosystems \& Environment 54(3): 125-128.

[4] Auber, L. (1965): Atlas des coléoptères de France, Belgique, Suisse. (TOM 1). - Editions N. Boubée, Paris.

[5] Avgin, S.S., Luff, M.L. (2010): Ground beetles (Coleoptera: Carabidae) as bioindicators of human impact. - Munis Entomology \& Zoology 5(1): 209-215.

[6] Balarin, I. (1974): Fauna Heteroptere na krmnim leguminozama i prirodnim livadama u SR Hrvatskoj. - Doctoral thesis, University of Zagreb, Zagreb, Croatia.

[7] Baranová, B., Fazekašová, D., Jászay, T., Manko, P. (2013): Ground beetle (Coleoptera: Carabidae) community of arable land with different crops. - Folis faunistica Slovaca 18(1): 21-29.

[8] Basedow, T. (1987): Der Einflu $\beta$ gesteigerter Bewirtschaftungs intensität in Getreidebau auf die Laufkäfer (Coleoptera: Carabidae). Mitteilungen aus der Biologischen Bundesanstalt für Land- und Forstwirtschaft, Berlin-Dahlem.

[9] Bažok, R., Kos T., Igrc Barčić, J., Kolak, V., Lazarević, B., Čatić, A. (2007): Abundance and distribution of the ground beetles Pterostichus melanarius (Illiger, 1798) and Pseudoophonus rufipes (DeGeer, 1774) in corn fields in Croatia. - Entomologia Croatica 11(1-2): 39-51.

[10] Bažok, R., Kos, T., Drmić, Z. (2015). Importance of ground beetles (Coleoptera: Carabidae) for biological stability of agricultural habitat, focus on cultivation of sugar beet. - Glasilo biljne zaštite 15: 264-276.

[11] Bechyne, J. (1974): Welcher Käfer ist das? Kosmos - Natürfuhrer, Stuttgart.

[12] Blake, S., Foster, G.N., Fischer, G.E.J., Ligertwood, G.L. (1996): Effects of management practices on the ground beetle faunas of newly established wildflower meadows in southern Scotland. - Annales Zoologici Fennici 33: 139-147.

[13] Blumberg, A.Y., Crossley Jr., D.A. (1983): Comparison of soil surface arthropod populations in conventional tillage, no-tillage and old field systems. - Agro-Ecosystems 8: 247-253.

[14] Bogunović, M., Vidaček, Ž., Racz, Z., Husnjak, S., Sraka, M. (1996): Namjenska pedološka karta 1:300000. - Department of Pedology, Faculty of Agriculture, University of Zagreb.

[15] Booij, K. (1994): Diversity in carabid assemblages in relation to crops and farming systems. - In: Desender, K., Dufrêne, M., Loreau, M., Luff, M.L., Maelfait, J.P. (ed.) Carabid Beetles Ecology and Evolution, Kluwer Academic Publishers, Dordrecht.

[16] Brigić, A., Starčević, M., Hrašovec, B., Elek, Z. (2014a): Old forest edges may promote the distribution of forest species in carabid assemblages (Coleoptera: Carabidae) in Croatian forests. - European journal of entomology 111(5): 715-725. 
[17] Brigić, A., Vujčić-Karlo, S., Matoničkin Kepčija, R., Stančić, Z., Alegro, A., Ternjej, I. (2014b): Taxon specific response of carabids (Coleoptera, Carabidae) and other soil invertebrate taxa on invasive plant Amorpha fruticosa in wetlands. - Biological invasions 16(7): 1497-1514.

[18] Brigić, A., Vujčić-Karlo, S., Stančić, Z. (2003): Carabidae fauna in different terrestrial habitats of Krapje Đol. - Bilten parka prirode Lonjsko polje 2: 13-26.

[19] Büchs, W., Prescher, S., Schmidt, L., Sivcev, L., Juran, I., Sivcev, I., Gotlin Čuljak, T., Graora, D., Grubisic, D. (2013): How winter oilseed rape areas differ in Germany and in the Western Balkans countries in terms of their carabid fauna (Coleoptera: Carabidae)? DGaaE-Nachrichten 27(3): 136-137.

[20] Bukejs, A., Balalaikins, M. (2008): Ground beetles (Coleoptera: Carabidae) of wheat agrocenosis in Latvia. - Acta Zoologica Lituanica 18(2): 134-138.

[21] Chapman, A.N. (2014): The Influence of Landscape Heterogeneity - Ground Beetles (Coleoptera: Carabidae) in Fthiotida, Central Greece. - Biodiversity Data Journal (2): e1082.

[22] Cole, L.J., McCracken, D.I., Dennis, P. (2002): Relationship between agricultural management and ecological groups of ground beetles (Coleoptera, Carabidae) on Scottish farmland. Agriculture Ecosystems \& Environment 93 (1-3): 323-336.

[23] Colwell, R. K. (2009). Biodiversity: concepts, patterns, and measurement. - The Princeton guide to ecology, 257-263.

[24] Douglas, M.R., Rohr, J.R., Tooker, J.F. (2014): Neonicotinoid insecticide travels through a soil food chain, disrupting biological control of non-target pests and decreasing soya bean yield. - Journal of Applied Ecology. doi: 10.1111/1365-2664.12372

[25] Drmić, Z., Čačija, M., Virić Gašparić, H., Lemic, D., Bažok, R. (2016): Endogaeic ground beetles fauna in oilseed rape field in Croatia. - Journal of Central European Agriculture 17(3): 675-684.

[26] Durbešić, P. (1982): Fauna kornjaša (Coleoptera) u šumskim zajednicama Gorskog kotara. Doctoral thesis - University of Zagreb, Zagreb, Croatia.

[27] Durbešić, P. (1987): Usporedba zoogeografskih karakteristika vrsta Coleoptera u livadnim zajednicama uz tokove Rijeka Mirne i Raše. - Ekologija 22(1): 1-20.

[28] Durbešić, P., Vujčić-Karlo, S., Šerić Jelaska, L., Pintarić, K. (2006): Abundance and seasonal dynamics of arthropods in the meadow community Arrhenatheretum elatioris near Varaždin, Croatia. - Periodicum biologorum 108(1): 3-10.

[29] EUR-Lex. (2009): Directive 2009/128/EC of the European Parliament and of the Council of 21 October 2009 establishing a framework for Community action to achieve the sustainable use of pesticides (Text with EEA relevance). - Official Journal of the European Union, Special edition in Croatian 15(7): 253-268. http://data.europa.eu/eli/dir/2009/128/oj

[30] Ferguson, H.J., McPherson, R.M. (1985): Abundance and diversity of adult carabidae in four soybean cropping systems in Virginia. - Journal of Entomological Science 20: 163171.

[31] Freude, H., Harde, K.W., Lohse, G.A., Klausnitzer, B. (2006): Die Käfer Mitteleuropas. II Band. Adephaga 1. - Elsevier GmbH, München, Germany.

[32] Harde, K.W., Severa, F. (1984): Der Kosmos Käferführer, Kosmos - Natürfuhrer, Stuttgart.

[33] Hence, T., Grégorie-Wibo, C. (1987): Effect of agricultural practices on carabid populations. - Acta Phytopathologica et Entomologica Hungarica 22: 147-160.

[34] Hence, T., Grégorie-Wibo, C., Lebrun Ph. (1990): Agriculture and ground-beetle populations. The consequence of crop types and surrounding habitats on activity and species composition. - Pedobiologia 34: 337-346.

[35] Heydemann, B. (1955): Carabiden der Kulturfelder als ökologische. Indikatoren. Ber. 7. Wandervers. dt. Entomologen. 
[36] Holland, J.M. (2002): Carabid beetles: their ecology, survival and use in agroecosystems. - In: Holland, J.M. (ed.) The agroecology of Carabid beetles. Intercept, Andover, UK.

[37] Holland, J.M., Luff, M.L. (2000): The effects of agricultural practices on Carabidae in temperate agroecosystems. - Integrated Pest Management Reviews 5: 109-129.

[38] Holland, J.M., Reynolds, C.J.M. (2003): The impact of soil cultivation on arthropod (Coleoptera and Araneae) emergence on arable land. - Pedobiologia 47: 181-191.

[39] Honek, A., Jarosik, V. (2000): The role of crop density, seed and aphid presence in diversification of field communities of Carabidae (Coleoptera). - European Journal of Entomology 97: 517-525.

[40] House, G.J., All, N.J. (1981): Carabid beetles in soybean agroecosystems. Environmental Entomology 10: 194-196.

[41] House, G.J., Parmalee, R.W. (1985): Comparison of soil arthropods and earthworms from conventional and no-tillage agroecosystems. - Soil \& Tillage Research 5: 351-360.

[42] House, G.J., Stinner, B.R. (1983): Arthropods in no-tillage soybean agroecosystems: community composition and ecosystem interactions. - Environmental Management 7: 2328.

[43] Hůrka, K., Vesely, P., Farkač, J. (1996): Die Nutzung der Laufkäfer (Coleoptera: Carabidae) zur Indikation der Umweltqualität. - Klapalekiana 32: 15-26.

[44] Igrc Barčić, J., Kos, T., Bažok, R. (2008): The abundance and distribution of the ground beetles Pterostichus melanarius Ill. and Harpalus rufipes De Geer in corn fields in Croatia. - Celebrating Entomology: Contributions to Modern Science, Durban, South African Republic.

[45] IUSS Working Group WRB. (2015): World Reference Base for Soil Resources 2014, update 2015. International soil classification system for naming soils and creating legends for soil maps. - World Soil Resources Reports No. 106. FAO, Rome, http://www.fao.org/.

[46] Jeschke, P., Nauen, R., Schnidler, M., Elbert, A. (2011): Overview of the status and global strategy for neonicotinoids. - Journal of Agricultural and Food Chemistry 59: 2897-2908.

[47] Jost, L. (2006): Entropy and diversity. - Oikos 113(2): 363-375.

[48] Juran, I., Gotlin Čuljak, T., Büchs, W., Grubišić, D., Sivčev, I. (2013): Impact of various oilseed rape productions on biological potential of endogaeic active ground beetles (Coleoptera: Carabidae). - Pesticides and Beneficial Organisms IOBC/wprs Bulletin 90: 351.

[49] Kos, T., Bažok, R., Drmić, Z., Graša, Ž. (2013): Ground beetles (Coleoptera: Carabidae) in sugar beet fields as the base for conservation biological control. - Insect Pathogens and Entomoparasitic Nematodes" Biological Control- its unique role in integrated and organic production. IOBC-WPRS Bulletin 90: 353-357.

[50] Kos, T., Bažok, R., Igrc Barčić, J. (2006): Uloga istraživanja biološke raznolikosti u integriranoj zaštiti bilja. - Glasilo biljne zaštite 1: 23-24.

[51] Kos, T., Bažok, R., Igrc Barčić, J. (2011): Abundance and frequency of ground beetles in three maize fields in Croatia. - Journal of Environmental Protection and Ecology 12(3): 894-902.

[52] Kos, T., Bažok, R., Kozina, A., Šipraga, J., Dragić, S., Tičinović, A. (2010): Ground beetle (Carabidae) fauna at untreated and treated barley fields in Croatia. - Pesticides and Beneficial Organisms IOBC/wprs Bulletin 55: 79-84.

[53] Kovačević, Ž., Balarin, I. (1960): Prilog poznavanju faune Coleoptera i Hemiptera na lucerištima i djetelištima. - Zaštita bilja 57-58: 163-175.

[54] Kozina, A., Lemic, D., Bažok, R., Mikac, K.M., Mclean, C.M., Ivezić, M., Igrc Barčić, J. (2015): Climatic, Edaphic Factors and Cropping History Help Predict Click Beetle Coleoptera: Elateridae) (Agriotes spp.) Abundance. - Journal of Insect Science 15(1): 100 . 
[55] Kromp, B. (1990): Carabid beetles (Coleoptera: Carabidae) as bioindicators in biological and conventional farming in Austrian potato fields. - Biology and Fertility of Soils 9: $182-187$.

[56] Kromp, B. (1999): Carabid beetles in sustainable agriculture: a review on pest control efficacy, cultivation impacts and enhancement. - Agriculture Ecosystems \& Environment 74: $187-228$

[57] Lövei, G.L., Sunderland, K.D. (1996): Ecology and behavior of ground beetles (Coleoptera: Carabidae). - Annual Review of Entomology 41: 231-236.

[58] Maelfait, J. P., Desender, K. (1990): Possibilities of Short-term Carabid Sampling for Site Assessment Studies. - In: Stork, N.E.(ed.) The role of Ground Beetles in Ecological and Environmental Studies. Intercept, Andower.

[59] Margalef, D. R. (1958): Information theory in ecology. - Gen. Syst. 3: 36-71.

[60] Marković, N. (2009): Vegetation, fauna, and ecological characteristics of three types of habitats in Zaprešić (in croatian). Doctoral thesis. - University of Zagreb, Zagreb, Croatia.

[61] MATLAB. (2015): The MathWorks, Inc. - Natick, Massachusetts, United States (Trial version).

[62] Meissner, R.L. (1984): Zur Biologie und Ökologie der ripicolen Carabiden Bembidion femoratum Sturm und B. punctulatum Drap. II. Die Substratbindung. - Zoologische Jahrbücher. Abteilung für Systematik, Geographie und Biologie der Tiere 111: 369-383.

[63] O'Rourke, M.E., Liebman, M., Rice, M.E. (2008): Ground beetle (Coleoptera: Carabidae) assemblage in conventional and diversified crop rotation systems. - Environmental Entomology 37 (1): 121-130.

[64] Östman, Ö., Ekbom, B., Bengtsson, J., Weibull, A. (2001): Landscape Complexity and Farming Practice Influence the Condition of Polyphagous Carabid Beetles. - Ecological Applications. 11: 480-488.

[65] Penzar, I., Penzar, B. (2000): Agrometeorologija. - Školska knjiga, Zagreb.

[66] Patten, B. C. (1962): Species diversity in net phytoplankton of Raritan Bay. - J. Mar. Res. 20: 57-75.

[67] Pielou, E. C. (1966): Species-diversity and pattern-diversity in the study of ecological succession. - J. Theoret. Bioi. 10: 370-383.

[68] Pietraszko, R., De Clercq, R. (1982): Influence of organic matter on epigeic arthropods. Mededelingen Faculteit Landbouwwetenschappen Rijksuniversiteit, Gent 47(2): 721-728.

[69] Pollard, E., Hedges, III. (1968): The Effect of Removal of the Bottom Flora of a Hawthorn Hedge on the Carabidae of the Hedge Bottom. - Journal of Applied Ecology 5: 125-139.

[70] Popescu, I. E., Zamfirescu, Ş. R. (2004): Synecological Analysis of a Wheat Field Ground Beetles Community from Letea (Bacău District). - Analele Ştiinţifice ale Universității “Al. I. Cuza” Iaşi, seria Biologie Animală. 50: 173-183.).

[71] Porhajašová, J., Petřvalský, V., Peterková, V., Urminská, J. (2004): Vplyv agronomických praktík na výskyt populácie bystruškovitých (Carabidae, Coleoptera). Acta Fytotechnica et Zootechnica 7(1): 24-27.

[72] Raino, J., Niemelä, J. (2003): Ground beetles (Coleoptera: Carabidae) as bioindicators. Biodiversity \& Conservation. 12(3): 487-506.

[73] Sekulić, R. (1977): Sukcesija vrsta iz familije Carabidae u nekim agrobiocenozama Vojvodine. Doctoral thesis. - University of Novi Sad, Novi Sad, Republic of Serbia.

[74] Sekulić, R., Horvatovich, S., Šilješ, J. (1973): Prilog proučavanju familije Carabidae na poljima pod pšenicom u okolini Osijeka. - Zbornik prirodne nauke Matice Srpske 44: 8590.

[75] Šerić Jelaska, L. (2005): Ground beetles (Carabidae, Coleoptera) assemblage in forest communities of Medvednica Mt. (in croatian). Master's thesis. - University of Zagreb, Zagreb, Croatia.

[76] Sotherton, N. (1985): The Distribution and Abundance of Predatory Coleoptera Overwintering in Field Boundaries. - Annals of Applied Biology. 106: 17-21. 
[77] Stassart, P., Grégorie-Wibo, C. (1983): Influence du travail du sol sur les populations de carabides en grande culture, resultats preliminaires. - Mededelingen Faculteit Landbouwwetenschappen Rijksuniversiteit, Gent 48(2): 465-474.

[78] Stinner, B.R., McCartney, D.A., Van Doren Jr., D.M. (1988): Soil and foliage arthropod communities in conventional, reduced and no-tillage corn (maize, Zea mays, L.) systems: a comparison after 20 years of continuous cropping. - Soil \& Tillage Research 11: 147158.

[79] Štrbac, P. (1983): Fauna, bionomija i morfološko-taksonomske karakteristike klisnjaka i trčuljaka (Col.; Elateridae; Carabidae) u agroekološkim uslovima Slavonije i Baranje. Doctoral thesis. - University of Osijek, Osijek, Croatia.

[80] Szczepaniec, A., Creary, S.F., Laskowski, K.L., Nyrop, J.P., Raupp, M.J. (2011): Neonicotinoid insecticide imidacloprid causes outbreaks of spider mites on elm trees in urban landscapes. - PlosOne 6: e20018

[81] Thiele, H.U. (1977): Carabid beetles in their Environment: a Study on Habitat Selection by Adaptations in Physiology and Behaviour. - Springer, Berlin.

[82] Tischler, W. (1949): Grundzüge der terrestrischen Tierökologie. - Braunschweig, Friedrich Vieweg und Sohn, Germany.

[83] Tonhasca, A. (1993): Carabid beetle assemblage under diversified agroecosystems. Entomologia Experimentalis et Applicata 68: 279-285.

[84] Varvara, M., Chimisliu, C., Šustek, Z. (2012): Distribution and abundance of Calosoma uropunctatum Herbst 1784 (Coleoptera: Carabidae) in some agricultural crops in Romania, 1977-2010. Oltenia. Studii şi comunicări. - Ştiinșele Naturii 28(1): 79-90.

[85] Vician, V., Svitok, M., Kočik, K., Stašiov, S. (2015): The influence of agricultural management on the structure of ground beetle (Coleoptera: Carabidae) assemblages. Biologia 70(2): 240-251

[86] Vigna Taglianti, A. (2013): Fauna Europaea: Carabidae. - In: Audisio, P. (ed.) Fauna Europaea: Carabidae, Carabid beetles. Fauna Europaea version 2.6.2, http://www.faunaeur.org.

[87] Vigna Taglianti, A., Audisio, A.P., Biondi, M., Bologna, M.A., Carpaneto, G.M., De Biase, A., Fattorini, S., Piattella, E., Sindaco, R., Venchi, A., Zapparoli, M. (1999): A proposal for chorotype classification of the Near East fauna, in the framework of the Western Palearctic region. - Biogeographia 20: 31-59.

[88] Ward, K.E., Ward, R.N. (2001): Diversity and abundance of carabid beetles in shortrotation plantings of sweet-gum, maize and switchgrass in Alabama. - Agroforestry Systems 53: 261-267.

[89] Virić Gašparić, H., Drmić, Z., Čačija, M., Graša, Ž., Petrak, I., Bažok, R., Lemic, D. (2017): Impact of environmental conditions and agro-technical factors on ground beetle populations in arable crops. - Applied Ecology and Environmental Research 15(3): 697711.

[90] Witmer, J.E., Hough-Goldstein, F.A., Pesek, J.D. (2003): Ground-dwelling and foliar arthropods in four cropping systems. - Environmental Entomology 32: 366-376.

[91] Woodcock, B.A, Redhead, J., Vanbergen, A.J., Hulmes, L., Hulmes, S., Peyton, J., Nowakowski, M., Pywell, R.F., Heard, M.S. (2010): Impact of habitat type and landscape structure on biomass, species richness and functional diversity of ground beetles. Agriculture Ecosystems \& Environment 139: 181-186.

[92] Zhang, J.X., Drummond, F.A., Liebman, M. (1998): Effect of crop habitat and potato management practices on the population abundance of adult Harpalus rufipes (Coleoptera: Carabidae) in Maine. - Journal of Agricultural Entomology 15: 63-74. 